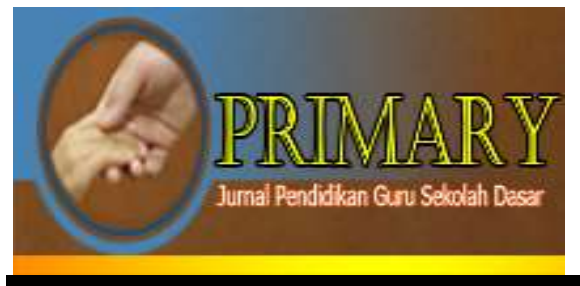

\author{
PRIMARY: JURNAL PENDIDIKAN GURU SEKOLAH DASAR \\ VOLUME 10 NOMOR 5 OKTOBER 2021 \\ ISSN : 2303-1514 | E-ISSN : 2598-5949 \\ DOI : http://dx.doi.org/10.33578/jpfkip.v10i5.8542 \\ https://primary.ejournal.unri.ac.id/index.php/JPFKIP
}

\title{
UTILIZING THE DISCUSSION METHOD TO IMPROVE TEACHERS' KNOWLEDGE ABOUT THE LEARNING PROCESS
}

\author{
Aminudin \\ Pengawas Sekolah, Rokan Hilir, Indonesia \\ aminudin2666@gmail.com

\section{PENERAPAN METODE DISKUSI DALAM MENINGKATKAN PENGETAHUAN GURU TENTANG PROSES PEMBELAJARAN}

\begin{tabular}{|c|c|}
\hline ARTICLE HISTORY & ABSTRACT \\
\hline $\begin{array}{l}\text { Submitted: } \\
18 \text { Juli } 2021 \\
18^{\text {th }} \text { July } 2021\end{array}$ & $\begin{array}{l}\text { Abstract: The main task of the school supervisor is to supervise the school for which he is } \\
\text { responsible. Supervision in this context includes monitoring, supervision, evaluation, reporting, } \\
\text { and taking the necessary follow-up steps. This School Action Research was carried out in the } \\
\text { fostered junior high school of Kabupaten Rokan Hilir under the supervision of the researcher. } \\
\text { This was chosen because it supported the task of school supervisors to find out and try to } \\
\text { improve teachers' competence in the learning process. The stages conducted in school action } \\
\text { research were: planning/preparing for action, implementing actions, observing and } \\
\text { interpreting, data analysis and reflection. From the results of the study, it was known that the } \\
\text { application of the discussion method improved teachers' understanding in the process of } \\
\text { learning activities. By using the discussion method, teachers' participation become more } \\
\text { active, meaning that it tended to be positive in following the process provided by the facilitator } \\
\text { as well as in conducting discussions within and between groups. This success was caused by } \\
\text { using the discussion method; teachers exchanged experiences, information with one another. In } \\
\text { other words, discussion techniques increased cooperation between teachers through the } \\
\text { exchange of opinions or information, so that they were more active. }\end{array}$ \\
\hline
\end{tabular}

Accepted:

04 Oktober 2021

$04^{\text {th }}$ October 2021

Keywords: discussion method, knowledge of the learning process

Abstrak: Tugas utama pengawas sekolah adalah melakukan pengawasan terhadap sekolah
yang menjadi tanggung jawabnya. Pengawasan dalam konteks ini meliputi pemantauan,
supervisi, evaluasi, pelaporan, dan pengambilan langkah tindak lanjut yang diperlukan.
Penelitian Tindakan Sekolah ini dilaksanakan di SMP Binaan Kabupaten Rokan Hilir dalam
satu pengawasan peneliti sendiri. Ini dipilih karena sangat menunjang tugas pengawas
Sekolah untuk mengetahui dan berusaha meningkatkan kompetensi guru dalam proses
pembelajaran. Adapun tahapan-tahapan yang dilalui dalam penelitian tindakan sekolah, yaitu:
Perencanaan/persiapan tindakan, Pelaksanaan tindakan, Observasi dan interpretasi, Analisis
data dan refleksi. Dari hasil penelitian diketahui bahwa penerapan metode diskusi dapat
meningkatkan pemahaman guru dalam proses kegiatan pembelajaran. Dengan menggunakan
metode disikusi partisipasi guru menjadi lebih aktif yang berarti cenderung positif dalam
mengikuti proses yang diberikan fasilitator maupun dalam melakukan diskusi di dalam dan
antar kelompoknya. Keberhasilan ini disebabkan dengan menggunakan metode diskusi guru
mampu saling bertukar pengalaman, informasi antara satu dengan yang lainnya. Dengan kata
lain teknik diskusi mampu meningkatkan kerjasama antar guru melalui tukar pendapat atau
informasi, sehingga mereka lebih aktif.
Kata Kunci: metode disikusi, pengetahuan tentang proses pembelajaran
CITATION
Aminudin, A. (2021). Utilizing the Discussion Method in Improving Teachers' Knowledge
about the Learning Process. Primary: Jurnal Pendidikan Guru Sekolah Dasar, 10 (5),
1298-1306. DOI: http://dx.doi.org/10.33578/jpfkip.v10i5.8542.

Published:

28 Oktober 2021

$28^{\text {th }}$ October 2021

agar dapat menyampaikan materi pelajaran

\section{PENDAHULUAN}

Guru mempunyai fungsi yang sangat penting dan sangat menentukan dalam proses pembelajaran (Miranda, Syahza, \& Sumarno, 2021). Seorang guru yang profesional dituntut dengan baik, efektif dan efisien sehingga siswa sebagai peserta didik mengerti dan memahami apa yang disampaikannya (Orunbon, \& IsaacPhilip, 2021). Guru dituntut pula menguasai 
berbagai strategi pembelajaran agar suasana pembelajaran di kelas lebih bergairah dan menyenangkan (Shofa, Su'ad, \& Murtono, 2021). Untuk mewujudkan tujuan tersebut, maka pengawas sekolah merupakan salah satu alat untuk mencapainya.

Sahertian (2000) mengemukakan bahwa guru memegang peranan yang amat penting dan strategis dalam proses pembelajaran, maka seorang guru harus kreatif dalam menemukan hal-hal baru untuk mencapai hasil pembelajaran yang optimal. Dalam pembelajaran di kelas, guru sebagai ujung tombak keberhasilan proses belajar mengajar terkadang kurang mempunyai kreativitas dalam menggunakan metode pembelajaran (Jawardi, 2021). Hal ini terlihat bahwa guru cenderung menggunakan metodemetode klasik seperti ceramah dan tanya jawab, sehingga kurang menggaraihkan guru dalam belajar dan tentunya akan berakibat pada rendahnya hasil belajar guru (Endriani, \& Yulita, 2021). Metode diskusi meupakan salah satu bentuk metode pembelajaran yang mengikutsertakan setiap guru dalam bertukar pendapat atau pikiran, sehingga ide-ide atau gagasan guru dapat tersalurkan (Azuar, 2021).

Keadaan di atas senada dengan pendapat yang dikemukakan oleh Roestiyah (2001) bahwa metode diskusi memiliki beberapa kelebihan seperti menyadarkan anak didik bahwa masalah dapat diselesaikan dengan berbagai jalan dan bukan satu jalan (satu jawaban saja), menyadarkan anak didik bahwa dengan berdiskusi mereka saling menukarkan pendapat secara konstruktif sehingga diperoleh keputusan yang lebih baik dan membiasakan anak didik untuk mendengarkan pendapat orang lain sekalipun berbeda dengan pendapatnya sendiri dan membiasakan bersikap toleran

Tugas utama pengawas sekolah adalah melakukan pengawasan terhadap sekolah yang menjadi tanggung jawabnya. Pengawasan dalam konteks ini meliputi pemantauan, supervisi, evaluasi, pelaporan, dan pengambilan langkah tindak lanjut yang diperlukan (Riyanta, 2021). Hal itu ditegaskan dalam Peraturan Pemerintah Nomor 19 Tahun 2005 tentang Standar Nasional Pendidikan Pasal 19 ayat (3) yang menetapkan setiap satuan pendidikan melakukan perencanaan proses pembelajaran, penilaian hasil pembelajaran, dan pengawasan proses pembelajaran untuk terlaksananya proses pembelajaran yang efektif dan efisien. Dilanjutkan dengan Pasal 23 yang menegaskan bahwa: Pengawasan proses pembelajaran sebagaimana dimaksud dalam pasal 19 ayat (3) meliputi pemantauan, supervisi, evaluasi, pelaporan, dan pengambilan langkah tindak lanjut yang diperlukan.

Berdasarkan pengamatan terhadap Guru di SMP Binaan Kabupaten Rokan Hilir dijumpai fenomena antara lain: 1) Adanya sebagian guru yang belum menjalankan tugas sesuai dengan ketentuan yang berlaku seperti mempersiapkan RPP, silabus maupun media pembelajaran, 2) Kurangnya inisiatif dan kreatifitas mengajar seperti mengadakan media dan sumber belajar yang mampu mengembangkan imajinasi anak, dan 3) Adanya sebagian guru yang kurang pemahamnya tentang landasan kependidikan, 4) adanya sebagian guru yang kurang memanfaatkan teknologi (computer maupun handphone) untuk tujuan pembelajaran.

$$
\text { Bagi terlaksananya tugas }
$$

kepengawasan yang profesional, efektif, dan efisien, maka pengawas pendidikan diharuskan menguasai sejumlah kompetensi (Maidar, 2021). Menurut Mockler (Aedi, 2014) bahwa pengawasan sebagai usaha sistematik menetapkan standar pelaksanaan dengan tujuan perencanaan, merancang sistem informasi umpan balik, membandingkan kegiatan nyata dengan standar, menentukan deviasi-deviasi dan mengambil tindakan koreksi yang menjamin bahwa semua sumber daya yang dimiliki telah dipergunakan dengan efektif dan efisien. 


\section{METODE PENELITIAN}

Penelitian Tindakan Sekolah ini dilaksanakan di SMP Binaan Kabupaten Rokan Hilir. Adapun tahapan-tahapan yang dilalui dalam penelitian tindakan sekolah, yaitu : perencanaan/ persiapan tindakan, pelaksanaan tindakan, observasi dan interpretasi, dan analisis data dan refleksi. Penelitian ini dilakukan dalam dua siklus. Lama waktu penelitian ini kurang lebih 1 bulan yaitu pada bulan Februari tahun 2020. Subjek yang diteliti adalah guru-guru di SMP Binaan pengawas, khususnya di SMP di Kecamatan Pasir Limau Kapas, Kubu dan Kubu Babussalam. Adapun jumlah sekolah binaan adalah 10 SMP terdiri dari 8 sekolah SMP Negeri dan 2 SMP Swasta. Untuk penetapan sampel peneliti menetapkan 2 orang guru dari masing masing SMP menjadi sampel. Dengan demikian jumlah sampelnya berjumlah 20 orang Guru.

Penelitian ini sejalan dengan penelitian tindakan kelas (Gimin, dkk, 2005) terdiri dari 2 siklus. Adapun setiap siklus dilakukan dalam 1 kali pertemuan. Adapun tiap siklus terdiri dari langkah-langkah, perencanaan/ persiapan tindakan, pelaksanaan tindakan, observasi dan interpretasi dan analisis data serta refleksi. Setelah hasil pada siklus I diperoleh dan telah direfleksi selanjunya dilakukan perbaikan untuk melanjutkan ke siklus II. Teknik pengumpulan dengan menggunakan instrument observasi dan tes sehingga dianalisis dengan cara mengklasifikasikan kemampuan guru.

\section{HASIL DAN PEMBAHASAN}

1. Siklus Pertama

a. Rencana (Plan)

Siklus I pada tanggal 3 Februari 2020 dan siklus II tanggal 10 Februari 2020. Jadwal penelitian ini memang diatur sedemikian rupa sehingga dalam satu minggu terdapat 1 kali pertemuan yaitu setelah guru-guru mengajar paginya. Perbaikan proses pembelajaran dengan menerapkan metode diskusi dalam siklus pertama, dikelola berdasarkan materi sebagaimana dalam proses belajar mengajar seperti cara menerapkan tujuan pembelajaran, materi/isi, metode yang digunakan dan media terakhir adalah penilaian. Proses pembelajaran diawali dengan memperkenalkan tujuan pembelajaran dan tahapan pembelajaran yang harus dilakukan guru. Mengawali kegiatan pendahuluan Fasilitator memotivasi guru dengan menjelaskan keterkaitan materi yang dipelajari dengan hal-hal yang dijumpai guru dalam kegiatan belajar mengajar sehari-hari.

Proses pembelajaran selanjutnya adalah penjelasan materi secara ringkas oleh peneliti dilajutkan dengan menyiapkan sarana dan prasarana yang diperlukan untuk diskusi. Guru menyusun peranan bagi tiap guru dalam diskusi dan berusaha menciptakan lingkungan yang kondusif agar tiap guru berani mengemukakan pendapatnya. Selama diskusi berjalan, Fasilitator melakukan bimbingan secara merata kepada seluruh kelompok. Selama guru mengerjakan tugas dan kelompoknya, Fasilitator mengawasi dan memberikan bantuan kepada kelompok yang memerlukannya. Setelah mengerjakan tugas kelompok sampai pada waktu yang ditentukan, guru menanyakan kesulitan yang masih dihadapi untuk didiskusikan bersama dan diklarifikasikan oleh guru. Disini para guru mengemukakan pendapatnya baik secara individu maupun berunding dengan anggota kelompoknya. Sebelum mengakhiri pembelajaran, peneliti membimbing guru menyimpulkan materi yang dipelajari.

\section{b. Tindakan (Action)}

Dalam melaksanakan tindakan yang direncanakan ternyata tidak sepenuhnya dapat direalisasikan. Sebahagian guru menyatakan keengganannya untuk belajar kelompok sepeti yang diatur. Mereka menganggap hal ini hanya membuang-buang waktu belajar dan dengan kelompok hanya memperlambat mereka mengerti terhadap masalah yang diajukan. Guru yang berkemampuan rendah cenderung menjadi lebih pasif, dan hanya menerima saja jawaban dari permasalahan yang diberikan tanpa ada andil untuk ikut serta dalam pemecahan permasalahan, akhirnya mereka 
mencari kesibukan sendiri dengan mengobrol. Anggapan seperti ini disampaikan oleh guru yang berkemampauan baik. Karena memang dari pasangan duduknya pada umumnya sudah terkondisi demikian. Guru yang berkemampuan baik duduknya dengan guru yang berkemampaun baik pula. Begitu pula guru yang berkemampuan rendah duduk berpasangan dengan berkemampuan rendah pula.

Peneliti merubah rencana semula dalam pembagian kelompok. Kelompok guru yang telah disusun guru tidak dijadikan pedoman dalam pembentukan kelompok berikutnya. Dengan memperhatikan keinginan guru tesebut, Fasilitator memutuskan bahwa kelompok guru dibagi menurut pasangan duduknya masing-masing. Mereka dapat memilih kelompok sebangkunya atau yang berdekatan dengan tempat duduknya. Dengan lebih dahulu menjelaskan metode belajar yang akan dilaksanakan, langkah berikutnya adalah guru mengajukan permasalahan yang telah dirancang untuk dipecahkan guru. Permasalahan yang dikemukakan dituliskan dipapan tulis, lalu kepada guru diminta mendiskusikan. Karena mereka belum terbiasa dengan metode seperti ini, guru perlu memberikan bimbingan ke setiap kelompok.

Setelah para guru mendiskusikan permasalahan yang diajukan dalam kelompok masing-masing, guru meminta satu atau dua kelompok untuk mengemukakan hasil temuannya. Dengan cara seperti ini diharapkan guru memiliki keberanian untuk menyatakan ide yang telah ditemukannya. Guru berperan memberi motivasi guna meningkatkan sikap dan minat guru terhadap proses pembelajaran yang berlangsung. Disamping itu, guru memberikan bimbingan dan membantu guru dalam kelompok untuk memperjelas masalah yang dikemukakan.

\section{c. Pengamatan (Observation)}

Berdasarkan pengamatan observer, secara umum pada saat menjelaskan materi bahan ajar guru terihat tertarik karena dalam menjelaskan materi peneliti langsung mencontohkannya ke dalam hal nyata yang dialami guru. Pada saat peneliti meminta guru menyebutkan contoh lain dari yang disebutkan peneliti banyak guru mengungkapkan pendapatnya. Guru terlihat sangat antusias untuk mendengarkan penjelasan guru dan mengungkapkan idenya. Minat guru ini antara lain didukung oleh hasil observasi "partisipasi guru" yang diukur dari 9 komponen, aktivitas guru tergolong cukup baik dengan persentase $43 \%$.

Kondisi terkait erat dengan aktivitas fasilitator. Dalam penerapan metode diskusi secara umum guru sudah melakukan dengan "cukup sempurna". Hal ini sesuai hasil pengamatan dimana aktivitas fasilitator memperoleh mencapai $60 \%$ dengan kategori baik. Hasil pengamatan aktivitas guru tersebut apabila dianalisis lebih jauh dan diskusikan dengan observer ditemukan beberapa kelemahan seperti berikut ini:

a. Dalam penyajian materi, fasilitaor masih kurang sistematis dan makan waktu cukup lama, serta kurang menggambarkan keterkaitan isi secara keseluruhan

b. Dalam membimbing pelaksanaan diskusi, fasilitator kurang serius dan kurang merata (terfokus pada kelompok tertentu saja).

c. Dalam pemberian hadiah yang berwujud "tepuk tangan" kurang disambut meriah oleh seluruh guru (kurang semarak) sehingga fungsi hadiah untuk menjadi motivator mungkin kurang bermanfaat. Hal ini ini disebabkan fasilitator kurang serius dalam menggerakkan anak atas pemberian hadiah tersebut.

d. Selain itu pada saat membimbing guru saat mengerjakan tugas yang diberikan peneliti mengakui masih belum optimal. Pengawasan dan bimbingan yang diberikan peneliti kepada guru belum merata khusunya kepada guru-guru yang belum mampu. Hal ini disebabkan ketidaksadaran peneliti dalam membimbing guru melakukan latihan terlalu lama berada pada suatu tempat. 
e. Dalam membangkitkan motivasi guru dalam belajar, peneliti menyadari belum optimal. Peneliti sering lupa memberikan penghargaan atas keberhasilan guru dalam belajar atau penghargaan atas hasil kerjanya. Di samping itu, motivasi dan dorongan khusunya kepada guru yang dianggap lemah untuk mengungkapkan ide-idenya masih kurang.
Berdasarkan data hasil tes yang dilakukan pada siklus I ini diperoleh rata-rata hasil belajar guru dalam mengikuti kegiatan ini sebesar 66\%. Bila kita lihat hasil tersebut secara garis besar bahwa ketuntasan secara klasikal dikatakan tidak tuntas $(<75)$. Secara detail distribusi hasil belajar pada siklus I dapat dilihat pada tabel berikut ini.

Tabel 1. Pengetahuan Guru Tentang Proses Pembelajaran Pada SIklus I

\begin{tabular}{clc}
\hline No & \multicolumn{1}{c}{ Pemahaman Guru Tentang Pembelajaran } & Persentase \\
\hline 1. & Pemahaman wawasan atau landasan kependidikan & $50 \%$ \\
2. & Pemahaman terhadap peserta didik & $80 \%$ \\
3. & Pengembangan kurikulum atau silabus & $80 \%$ \\
4. & Perancangan pembelajaran & $70 \%$ \\
5. & Pelaksanaan pembelajaran yang mendidik dan dialogis & $50 \%$ \\
6. & Pemanfaatan teknologi pembelajaran & $70 \%$ \\
7. & Evaluasi hasil belajar $\quad$ Rata-rata & $65 \%$ \\
& & $\mathbf{6 6 \%}$ \\
\hline
\end{tabular}

Sumber: Data Olahan Penelitian, 2020

\section{d. Refleksi (reflektion)}

Memperhatikan deskripsi proses pembelajaran yang dikemukakan di atas dan melihat hasil kegiatan fasilitator, maka berdasarkan hasil pembahasan peneliti dan pengamat terhadap perbaikan pembelajaran pada siklus pertama terdapat beberapa kekuatan dan kelemahan pembelajaran diantaranya:

a. Pengelolaan pembelajaran oleh fasilitator telah sesuai dengan tahapan maka penerapan metode diskusi dalam proses kegiatan ini guru masih mengalami beberapa kelemahan khususnya dalam penyajian materi yang kurang sistematis, kurang serius dalam membimbing, kurang semarak dalam pemberian hadiah, serta ketidaksamaan jumlah pertanyaan untuk masing-masing kelompok.

b. Motivasi dan keantusiasan guru mengikuti pembelajaran cukup baik.

c. Secara umum partisipasi guru dalam belajar sudah mulai terfokus pada tugastugas belajarnya namun masih perlu pengawasan yang lebih ketat karena masih banyak yang terlihat mengobrol. d. Kemandirian guru dalam membangun pengetahuannya belum optimal, karena guru masih belum terbiasa dan baru dilaksanakan 1 kali.

Tindakan yang dilakukan fasilitator pada tahap awal masih membingungkan guru. Sebagian guru meminta fasilitator untuk cepat memberikan jawaban dari permasalahan yang diajukan, hanya sebagian kecil guru yang berusaha untuk tetap menemukan pemecahan dari permasalahan yang diajukan. Peran fasilitator dalam membimbing guru masih sangat dibutuhkan untuk memecahkan masalah yang diajukan, ini dapat dilihat dari ketergantungan guru terhadap bimbingan fasilitator masih sangat dominan.

Guru sulit untuk memecahkan permasalahan yang diberikan fasilitator oleh karena tidak memiliki sumber informasi selain fasilitator. Kebanyakan guru belum mempunyai kepercayaan diri bahwa mereka memiliki kemampuan untuk dapat memecahkan masalah sendiri. Jika diperhatikan hasil berlajar yang diperoleh guru ada sedikit peningkatan dari hasil kuis yang diberikan pada pertemuan. Dari aspek afektif 
guru memiliki sikap yang cukup positif dan minat yang masih sedikit kurang antusias untuk turut melibatkan diri dalam memecahkan permasalahan yang ada pada saat diskusi. Namun demikian guru harus lebih memberikan perhatian khusus terutama pada guru yang menunjukkan sikap, minat, dan hasil belajar yang masih rendah.

Berdasarkan hal di atas perlu diadakan siklus berikutnya. Kekurangan yang perlu diatasi dari siklus pertama adalah: 1) Kapada guru yang sikapnya dan minatnya cukup serta nilai hasil belajar kognitif rendah perlu diberikan perhatian khusus dengan membimbing mereka secara individual. 2) Oleh karena waktu yang dibutuhkan guru untuk memecahkan permasalahan yang diberikan cendruing lama, maka guru perlu memberikan batasan waktu kepada guru untuk memecahkan masalah. 3) Kecuali kepada guru yang masih bernilai rendah, bimbingan guru terhadap guru lainnya perlu dikurangi untuk menumbuhkan kepercayaan diri bahwa mereka mampu memecahkan masalah sendiri. Hal ini juga berguna untuk memastikan bahwa hasil belajar yang diperoleh guru harus lebih banyak berkat usaha guru, bukan karena bimbingan kepala sekolah.

\section{Siklus Kedua}

Proses kegiatan belum memberikan hasil yang optimal. Ini dapat dilihat dari hasil tes belajar pada siklus pertama yang menunjukkan menunjukkan bahwa secara ratarata belum mencapai yang diharapkan tercapai (rata-rata 66\%). Agar lebih mengoptimalkan hasil bimbingan maka perlu dirancang suatu tindakan untuk dilaksanakan pada siklus kedua. Tindakan pada siklus kedua dimaksudkan untuk memperbaiki tindakan pada siklus I. Tindakan utama pada siklus I tetap dilaksanakan pada siklus II yaitu penerapan metode diskusi tanggal 10 Februari 2020.

\section{a. Rencana (plan)}

Waktu pelaksanaan siklus kedua berlangsung dalam satu minggu setelah selesainya siklus pertama. Pertemuan pertama dan kedua pada siklus II ini berlangsung pada tanggal 10 Februari 2020. Berdasarkan refleksi pada siklus pertama yang telah dilakukan peneliti merencanakan beberapa hal yaitu: 1) Guru tetap bekerjasama secara berkelompok menurut tempat duduknya masing-masing seperti yang dilakukan pada siklus pertama, 2) fasilitator memberi perhatian atau bimbingan khusus kepada guru yang mengalami masalah pada siklus pertama. Bimbingan khusus yang diberikan adalah dengan memberikan perhatian tersendiri, memberikan lebih banyak contoh-contoh yang relevan, menanyakan kesulitan apa yang temui dalam memecahkan masalah, memberikan penghargaan atau dorongan kepada guru atau kelompok dalam memecahkan masalah, 3) Memberikan batas waktu pada guru dalam memecahkan permasalahan yang diberikan misalnya; permasalahan yang diberikan dalam waktu 15 menit atau waktu 20 menit tergantung pada banyaknya permasalahan yang diajukan.

\section{b. Tindakan (Action)}

Proses pembelajaran pada siklus kedua pertama-tama fasilitator memotivasi guru dengan mengumumkan nilai hasil test kognitip diakhir siklus pertama atau pada pertemuan kedua. Selanjutnya fasilitator memberikan pujian bagi nilainya bagus dan dorongan bagi yang belum bagus. Seperti pada siklus pertama, pada setiap pertemuan fasilitator mengajukan permasalahan untuk dipecahkan oleh guru. Para guru diminta untuk mendiskusikan dengan teman sebangkunya dengan memecahkan masalah yang berkaitan dengan pemerintahan pusat. Sehingga masingmasing guru/kelompok guru mempunyai permasalahan permasalahan yang berbeda. Kemudian guru diminta menyampaikan tanggapannya atau hasil temuannya. Fasilitator memberikan kesempatan kepada guru untuk berani mengemukakan pendapatnya dan berani 
untuk bertanya jika menemukan kesulitan dalam memecahkan permasalahan mereka.

Kepada guru yang sebelumnya diketahui memiliki nilai rendah diberikan pembelajaran secara individual. Fasilitator memberikan rangsangan dengan pertanyaanpertanyaan atau tidak langsung memberikan jawaban atas pertanyaan yang mereka ajukan kepada guru. Untuk guru yang lain, mereka diminta berdiskusi dengan teman sebangku/berdekatan atau mempelajari dari buku pegangan yang mereka miliki. Jika memang terbentur guru diberi kesempatan untuk bertanya.

Pada setiap kali masalah diajukan, fasilitator memberitahukan kepada guru berapa lama untuk menyelesaikan. Walaupun pembatasan waktu ini tidak sepenuhnya sesuai dengan yang direncanakan namun dapat dilihat bahwa guru berusaha untuk memecahkan permasalahan sesuai dengan batas waktu yang diberikan.

\section{c. Pengamatan (Observation)}

Seperti halnya pada siklus pertama, pengamatan didasarkan pada dua hal yaitu; 1) Hasil pengamatan langsung yang dilakukan oleh observer untuk mengetahui aktivitas fasilitator dalam Penerapan metode diskusi dan aktivitas guru selama kegiatan berlangsung, dan 2) hasil kegiatan guru. Hasil pengamatan diperoleh dari dua kali pertemuan. Satu kali pertemuan untuk memecahkan dua permasalahan dan satu berikutnya masingmasing untuk satu kali pertemuan. Kuis yang diberikan pada siklus kedua sebanyak dua kali sesuai dengan rencana pembelajaran yang disusun sebelumnya. Adapun hasil pengamatan pada siklus II menunjukkan peningkatan baik dari aktivitas fasilitator dan partisipasi guru dalam kegiatan tersebut.

Berdasarkan pengamatan observer berkaitan dengan kemampuan fasilitator pada siklus I melalui hasil observasi yang diukur dari 9 komponen, aktivitas guru memperoleh $43 \%$. Sedangkan hasil observasi pada Siklus II mencapai persentase sebesar $78 \%$ yang tergolong sangat baik. Berdasarkan data tersebut di atas, diketahui bahwa adanya peningkatan dari $43 \%$ menjadi $78 \%$ dipengaruhi khususnya dalam hal menyampaikan materi dan memberikan motivasi kepada guru selama pembelajaran.

Adapun mengenai aktivitas fasilitator dalam menggunakan metode diskusi, jika pada siklus I guru sudah melakukan dengan "baik" dengan persentase $60 \%$. Hasil pengamatan aktivitas guru pada siklus II menunjukkan adanya peningkatan dengan persentase $89 \%$ dengan kriteria sangat baik. Berdasarkan data hasil tes formatif yang dilakukan pada siklus I diperoleh rata-rata Pengetahuan Guru Tentang proses pembelajaran mencapai $61 \%$. Sedangkan pada siklus II, rata-rata kemampuan guru sebesar $86 \%$. seperti terlihat pada tabel berikut ini.

Tabel 2. Pengetahuan Guru Tentang Proses Pembelajaran Siklus II

\begin{tabular}{clc}
\hline No & \multicolumn{1}{c}{ Pemahaman Guru Tentang Pembelajaran } & Persentase \\
\hline 1. & Pemahaman wawasan atau landasan kependidikan & $75 \%$ \\
2. & Pemahaman terhadap peserta didik & $80 \%$ \\
3. & Pengembangan kurikulum atau silabus & $85 \%$ \\
4. & Perancangan pembelajaran & $90 \%$ \\
5. & Pelaksanaan pembelajaran yang mendidik dan dialogis & $60 \%$ \\
6. & Pemanfaatan teknologi pembelajaran & $75 \%$ \\
7. & Evaluasi hasil belajar $\quad$ Rata-rata & $90 \%$ \\
& & $\mathbf{7 9 \%}$ \\
\hline
\end{tabular}

Sumber: Data Penelitian, 2020

Tabel di atas menunjukkan bahwa secara rata-rata telah mencapai ketuntasan (rata-rata 79\%). Hal ini yang perlu diungkapkan dari pengamatan pada siklus 
kedua adalah bahwa masalah-masalah yang telah berhasil merangsang guru untuk berfikir aktif dibanding siklus pertama.
Perbandingan antara hasil peningkatan pemahaman guru pada Siklus I dan Siklus II secara jelas dapat dilihat pada Tabel berikut ini.

\section{Pembahasan}

Tabel 3. Rekapitulasi Pengetahuan Guru Tentang Proses Pembelajaran

\section{Siklus I dan Siklus II}

\begin{tabular}{clcc}
\hline No & \multicolumn{1}{c}{ Pemahaman Guru Tentang Pembelajaran } & Silus I & Siklus II \\
\hline 1. & Pemahaman wawasan atau landasan kependidikan & $50 \%$ & $75 \%$ \\
2. & Pemahaman terhadap peserta didik & $80 \%$ & $80 \%$ \\
3. & Pengembangan kurikulum atau silabus & $80 \%$ & $85 \%$ \\
4. & Perancangan pembelajaran & $70 \%$ & $90 \%$ \\
5. & Pelaksanaan pembelajaran yang mendidik dan dialogis & $50 \%$ & $60 \%$ \\
6. & Pemanfaatan teknologi pembelajaran & $70 \%$ & $75 \%$ \\
7. & Evaluasi hasil belajar & $65 \%$ & $90 \%$ \\
& Rata-rata & $\mathbf{6 6 \%}$ & $\mathbf{7 9 \%}$ \\
\hline
\end{tabular}

Berdasarkan tabel di atas diketahui bahwa terjadinya peningkatan pemahaman dari siklus I ke siklus II. Jika pada siklus I kemampuan guru tentang proses pembelajaran hanya mencapai rata-rata $66 \%$ maka pada siklus II meningkat menjadi $79 \%$. Meningkatnya pemahaman guru pada siklus dua dibandingkan pada siklus I menunjukkan bahwa metode diskusi memecahkan permasalahan yang dihadapi. Artinya bahwa perencanaan pembelajaran yang dibuat sesuai untuk mengatasi permasalahan proses pembelajaran yang terjadi selama ini. Selanjutnya, adanya peningkatan pemahaman guru dari sebelumnya kesiklus I dan ke siklus II menunjukkan bahwa Penerapan metode diskusi dapat meningkatkan Pengetahuan Guru Tentang kegiatan pada proses pembelajaran yang terjadi di kelas yang selama ini para guru laksanakan.

Hal ini senada dengan pendapat yang dikemukakan oleh Suryosubroto (2002:185) bebrapa keuntungan penggunan metode diskusi antara lain, melibatkan semua siswa secara langsung dalam proses belajar, dapat menguji tingkat pengetahuan dan penguasaan bahan pelajarannya masing-masing, metode diskusi dapat menumbuhkan dan mengembangkan cara berfikir dan sikap ilmiah, dan dengan mengajukan dan mempertahankan pendapatnya dalam diskusi diharapkan para siswa akan dapat memperoleh kepercayaan akan (kemampuan) diri sendiri. Dari kuntungan yang dimiliki oleh metode diskusi di atas bahwa metode diskusi adalah meningkatkan minat dan keaktifan yang pada giliranya dapat meningkatkan pemahaman jika dilaksanakan dengan baik sesuai dengan situasi dan kondisi yang terjadi pada saat kegiatan dilaksanakan.

\section{SIMPULAN DAN SARAN}

Analisis permasalahan yang telah dikemukakan di atas, dapat diambil suatu kesimpulan bahwa Penerapan metode diskusi dapat meningkatkan pemahaman guru dalam proses kegiatan pembelajaran. Dengan menggunakan metode disikusi partisipasi guru menjadi lebih aktif yang berarti cenderung positif dalam mengikuti proses yang diberikan fasilitator maupun dalam melakukan diskusi di dalam dan antar kelompoknya. Keberhasilan ini disebabkan dengan menggunakan metode diskusi guru mampu saling bertukar pengalaman, informasi antara satu dengan yang lainnya. Dengan kata lain teknik diskusi mampu meningkatkan kerjasama antar guru melalui tukar pendapat atau informasi, sehingga mereka lebih aktif. 
Hasil penelitian yang dikemukakan di atas, berkaitan dengan penerapan metode diskusi yang telah dilaksanakan, peneliti mengajukan beberapa saran, yaitu:

1. Agar pelaksanaan penerapan metode diskusi tersebut dapat berjalan dengan baik, maka sebaiknya fasilitator lebih sering menerapkannya.

2. Dalam penerapan metode diskusi, sebaiknya fasilitator dapat memilihkan tingkat permasalahan yang harus dibatasi.

\section{DAFTAR PUSTAKA}

Azuar, A. (2021). The Implementation of Discussion Method through Zoom Meeting for PKN Learning during the Pandemic Period. Jurnal PAJAR (Pendidikan dan Pengajaran), 5(3), 703-709. DOI http://dx.doi.org/10.33578/pjr.v5i3.839 $\underline{6}$.

Aedi, N. (2014). Pengawasan Pendidikan, Tinjauan Teori dan Praktek. Jakarta: Raja Grafindo Persada.

Endriani., \& Yulita, F. (2021). Academic Supervision in Improving Teachers' Skills during the Learning Process at Elementary School. Jurnal PAJAR (Pendidikan dan Pengajaran), 5(5), 1475-1482. DOI http://dx.doi.org/10.33578/pjr.v5i5.851 $\underline{5}$.

Gimin, dkk. (2005). Pedoman Penulisan Karya Ilmiah Mahasiswa. FKIP. UNRI.

Jawardi. (2021). Training by Using Zoom Meeting to Improve Teaching Skills at SDN 017 Sungai Gantang. Jurnal PAJAR (Pendidikan dan Pengajaran), 5(5), 1434-1442. DOI : http://dx.doi.org/10.33578/pjr.v5i5.848 8.

Miranda, M., Syahza, A., \& Sumarno. (2021). Analysis of Factors Affecting Teacher
Performance in State Junior High School Learning in Bengkalis Regency. Journal of Educational Sciences, 5(3), 464-478.

Maidar, M. (2021). Implementing Demonstration Method to Improve Teachers' Pedagogic Competence during the Covid-19 Pandemic at SLB Melati Rumbai. Primary: Jurnal Pendidikan Guru Sekolah Dasar, 10 (4), 892-903. DOI: http://dx.doi.org/10.33578/jpfkip.v10i4 .8468 .

Orunbon, N. O., \& Isaac-Philip, M. M. (2021). School Organisational Silence, Teachers' Job Commitment and Productivity in Senior Secondary Schools Education District I of Lagos State, Nigeria. Journal of Educational Sciences, 5(3), 569-583.

Roestiyah. (2001). Strategi Belajar Mengajar. Rineka Cipta, Jakarta.

Riyanta, A. (2021). Implementing Academic Supervision to Improve Teachers' Skills in Implementing Study From Home Program (SFH) During the Covid-19 Pandemic. Primary: Jurnal Pendidikan Guru Sekolah Dasar, 10 (4), 909-923. DOI: http://dx.doi.org/10.33578/jpfkip.v10i4 .8469 .

Shofa, A., Su'ad, S., \& Murtono, M. (2021). Developing Integrative Thematic Materials Based on Local Wisdom on Science Subject of Theme 3, Healthy Food, at Grade V. Jurnal PAJAR (Pendidikan dan Pengajaran), 5(5), 1386-1396. DOI http://dx.doi.org/10.33578/pjr.v5i5.817 1 .

Sahertian. (2000). Supervisi Pendidikan. Jakarta Rineka Cipta. 